\title{
Rubrocerebellar Feedback Loop Isolates the Interposed Nucleus as an Independent Processor of Corollary Discharge Information in Mice
}

\author{
Christy S. Beitzel, ${ }^{1}$ Brenda D. Houck, ${ }^{2}$ Samantha M. Lewis, ${ }^{2}$ and Abigail L. Person ${ }^{2}$ \\ ${ }^{1}$ Neuroscience Graduate Program, and ${ }^{2}$ Department of Physiology and Biophysics, University of Colorado School of Medicine, Aurora, Colorado 80045
}

Understanding cerebellar contributions to motor coordination requires deeper insight into how the output structures of the cerebellum, the cerebellar nuclei, integrate their inputs and influence downstream motor pathways. The magnocellular red nucleus (RNm), a brainstem premotor structure, is a major target of the interposed nucleus (IN), and has also been described in previous studies to send feedback collaterals to the cerebellum. Because such a pathway is in a key position to provide motor efferent information to the cerebellum, satisfying predictions about the use of corollary discharge in cerebellar computations, we studied it in mice of both sexes. Using anterograde viral tracing, we show that innervation of cerebellum by rubrospinal neuron collaterals is remarkably selective for the IN compared with the cerebellar cortex. Optogenetic activation of the pathway in acute mouse brain slices drove IN activity despite small amplitude synaptic currents, suggesting an active role in IN information processing. Monosynaptic transsynaptic rabies tracing indicated the pathway contacts multiple cell types within the IN. By contrast, IN inputs to the RNm targeted a region that lacked inhibitory neurons. Optogenetic drive of IN inputs to the RNm revealed strong, direct excitation but no inhibition of RNm neurons. Together, these data indicate that the cerebellar nuclei are under afferent control independent of the cerebellar cortex, potentially diversifying its roles in motor control.

Key words: cerebellar nuclei; cerebellum; feedback loops; Purkinje; red nucleus; sensorimotor integration

Significance Statement

The common assumption that all cerebellar mossy fibers uniformly collateralize to the cerebellar nuclei and cortex underlies classic models of convergent Purkinje influence on cerebellar output. Specifically, mossy fibers are thought to both directly excite nuclear neurons and drive polysynaptic feedforward inhibition via Purkinje neurons, setting up a fundamental computational unit. Here we present data that challenge this rule. A dedicated cerebellar nuclear afferent comprised of feedback collaterals from premotor rubrospinal neurons can directly modulate IN output independent of Purkinje cell modulation. In contrast to the IN-RNm pathway, the RNm-IN feedback pathway targets multiple cell types, potentially influencing both motor output pathways and nucleo-olivary feedback.

\section{Introduction}

Prominent theories of cerebellar contributions to motor control propose that the cerebellum computes a prediction of body kine-

\footnotetext{
Received April 23, 2017; revised Sept. 1, 2017; accepted Sept. 12, 2017.

Author contributions: C.S.B. and A.L.P. designed research; C.S.B., B.D.H., S.M.L., and A.L.P. performed research; C.S.B. and A.L.P. analyzed data; C.S.B. and A.L.P. wrote the paper.

This work was supported by NIH R01 NS084996, the Klingenstein and McKnight Foundations to A.L.P., and F31 NS096887 to C.S.B. Light microscopy was performed in the University of Colorado Anschutz Medical Campus Advance Light Microscopy Core, and optogenetics support was provided by the University of Colorado Optogenetics and Neural Engineering Core; both cores are supported in part by Rocky Mountain Neurological Disorders Core Grant P30NS048154 and by NIH/NCRR Colorado CTSI Grant UL1 RR025780. We thank Jesse Gilmer for advice on cerebellar volume measurements and Cristin Welle and colleagues for advice on the paper.

The authors declare no competing financial interests.

Correspondence should be addressed to Dr. Abigail L. Person, 12800 East 19th Avenue, RC1 North Room 7402K, Aurora, C0 80045. E-mail: abigail.person@ucdenver.edu.
}

matics, termed a forward model (Kawato and Gomi, 1992; Wolpert et al., 1998). Because sensory feedback is too slow to guide most fast movements, forward models provide a framework for online motor corrections, facilitating fast and accurate movements. Evidence that the cerebellum is a source of predictive coding has accumulated in recent years (Pasalar et al., 2006; Herzfeld et al., 2015), raising the question of how this computation is made. Outgoing motor commands, communicated via corollary discharge pathways, are essential to compute a forward model (Wolpert, 1997). Many inputs to the cerebellum are thought to convey a mix of both sensory and motor information. However,

B. D. Houck's present address: Department of Biology, Hendrix College, Conway, AR 72032.

DOI:10.1523/JNEUROSCI.1093-17.2017

Copyright $\odot 2017$ the authors $\quad 0270-6474 / 17 / 3710085-12 \$ 15.00 / 0$ 
cerebellar inputs arising from the magnocellular region of the red nucleus (RNm) are an interesting candidate likely to provide the cerebellum with real time motor information (Brodal and Gostad, 1954; Courville and Brodal, 1966; Anderson, 1971; Eccles et al., 1975; Huisman et al., 1983).

The RNm is a premotor structure that projects directly to motor neurons and premotor pools in the spinal cord that innervate limb musculature (Murray and Gurule, 1979; Huisman et al., 1981; Kohlerman et al., 1982; Gibson et al., 1985). Dual-color retrograde dye injections into the spinal cord and cerebellar interposed nucleus (IN) revealed colabeled neurons in the RNm, suggesting that RNm projections to the cerebellum are collaterals of the rubrospinal tract, potentially providing the cerebellum with another source of corollary discharge information (Huisman et al., 1983). However, there is debate whether RNm projects mainly to the cerebellar cortex, the IN or both (Hinman and Carpenter, 1959; Courville and Brodal, 1966; Courville, 1968; Huisman et al., 1983; Naus et al., 1984; Walberg and Dietrichs, 1986). Indeed, if RNm projects mainly to the cerebellar nuclei it would be in a position to facilitate computations independent of the cerebellar cortex, potentially setting up a comparator circuit with convergent Purkinje afferents. Because the rubrocerebellar pathway has only been examined using retrograde tracing, this debate has gone largely unresolved. Although it is often assumed that excitatory innervation of the cerebellar nuclei is dominated by collaterals of precerebellar afferents producing either mossy fibers or climbing fibers, the literature on single cell fills of mossy fibers reveals large heterogeneity in the degree of collateralization of mossy fibers to the nuclei (Wu et al., 1999; Quy et al., 2011; Luo and Sugihara, 2014).

Of course, RNm is also a major target of cerebellar output. Therefore, a projection back to the IN would form a reciprocal loop between these two structures. Previous studies have shown that ablation of cerebellar cortical inhibition causes prolonged depolarization of IN neurons, suggestive of a reverberating circuit between IN and its targets (Tsukahara et al., 1983). Moreover, excitatory feedback loops are seen throughout the motor system and are important for models of neural control of movement (Cannon et al., 1983; Anastasio and Robinson, 1989; Houk et al., 1993). However, because the IN and RNm contain multiple cell types, including both excitatory and inhibitory neurons, the nature of the reciprocal circuitry between these structures was unclear, particularly for the rubrocerebellar pathway.

In the current study, we investigated the feedback loop between the RNm and the cerebellum, using a variety of viral tracing methods, slice electrophysiology, and optogenetics. We focused on differences between innervation patterns of cerebellar cortex and nuclei, the cell types engaged by feedback pathways, and the short-term plasticity characteristics of the rubrocerebellar and cerebello-rubral pathways. Our results on the RNm-IN loop point to the cerebellar nuclei as an independent locus for cerebellar processing and provide evidence suggesting different computational hubs within the cerebellum, because of different precerebellar innervation patterns of nuclei and cortex.

\section{Materials and Methods}

Animals

All procedures followed the National Institutes of Health Guidelines and were approved by the Institutional Animal Care and Use Committee at the University of Colorado Anschutz Medical Campus. Animals were housed in an environmentally controlled room, kept on a $12 \mathrm{~h}$ light/dark cycle and had ad libitum access to food and water. Adult mice of either sex were used in all experiments. Genotypes used were C57BL/6 (Charles
River Laboratories), Neurotensin receptor1-Cre [Ntsr1-Cre; Mutant Mouse Regional Resource Center, STOCK Tg(Ntsr1-cre) GN220Gsat/ Mmucd], GlyT2.eGFP [Salk Institute; Zeilhofer et al., 2005; Tg(Slc6a5EGFP)13Uze], Gad1-Cre (Higo et al., 2009), and Ail4 mice (The Jackson Laboratory; Gt(ROSA)26Sor ${ }^{\mathrm{tm} 14}(C A G-t d$ Tomato $\left.) \mathrm{Hze}\right]$. All transgenic animals were bred on a C57BL/6 background and maintained as heterozygotes. Ntsr1.Cre and Gad1.Cre animals were genotyped for Cre, and GlyT2.eGFP animals were genotyped for eGFP (Transnetyx).

\section{Biotinylated dextran amine injections}

For all surgical procedures mice were anesthetized with intraperitoneal injections of a ketamine hydrochloride $(100 \mathrm{mg} / \mathrm{kg})$ and xylazine $(10 \mathrm{mg} / \mathrm{kg})$ cocktail, placed in a stereotaxic apparatus, and prepared for surgery with a scalp incision. For RNm injections, craniotomies were made bilaterally above the RNm injections (from bregma: $-3.5 \mathrm{~mm}, 0.6$ $\mathrm{mm}$ lateral, $3.6 \mathrm{~mm}$ ventral). For IN injections, bilateral injections were made at lambda: $-2.0 \mathrm{~mm}$ posterior, $1.5 \mathrm{~mm}$ lateral, $2.3 \mathrm{~mm}$ ventral. Iontophoretic injections of $10 \%$ biotinylated 10,000 dextran amine (BDA; Invitrogen) were administered using a pulled glass pipette $(30-40$ $\mu \mathrm{m}$ tip diameter) at 5-6.5 $\mu \mathrm{A}$ for $8-10 \mathrm{~min}$ and a 50:50 duty cycle. Mice were allowed to survive for 7-14 $\mathrm{d}$ before sacrifice.

\section{Virus injections}

Retrograde viral tracing of rubrocerebellar pathway. Craniotomies were made over the RNm and IN in C57BL/6 mice. AAV8.mCherry.Cre (200 nl; University of North Carolina [UNC] Vector Core) was injected bilaterally in the RNm, along with bilateral injection of AAV1.CAG.Flex.eGFP.WPRE.bGH (AAV1.Flex.eGFP; University of Pennsylvania Vector Core) into the IN. Animals were allowed to survive for 14-21 d before perfusion.

Anterograde tracing of RNm-IN pathway. Bilateral pressure injections of 150-250 nl of either AAV1.hSyn1.mCherry (UNC Vector Core) or AAV1.hSyn1.eYFP (UNC Vector Core) were made into the RNm in C57BL/6 mice. All mice injected with AAVs were housed postoperatively for 4-6 weeks before perfusion to allow for viral expression throughout the entirety of the axonal arbor.

Anterograde viral tracing of IN-RNm afferents. Bilateral pressure injections of eitherAAV1.hSyn1.mCherry(UNCVectorCore) or AAV1.hSyn1. eYFP (UNC Vector Core) were made in the IN of C57BL/6, GlyT2.eGFP, or Gad1-Cre mice. In a subset of experiments, AAV1.CAG.FLEX.eGFP injections were made into the IN of Gad1-Cre mice to label GABAergic neurons. Mice were housed postoperatively for 6 weeks before perfusion.

Anterograde viral tracing of pontocerebellar pathway. Bilateral pressure injections of AAV1.hSyn1.eYFP (UNC Vector Core) were made into the basilar pontine nuclei, with injection coordinates (from bregma) -4.0 to $4.5 \mathrm{~mm}, 0.4 \mathrm{~mm}$ lateral, and $5.5 \mathrm{~mm}$ ventral. Mice were housed postoperatively for 4-6 weeks before perfusion.

Monosynaptic rabies retrograde tracing. AAV1.EF1.Flex.TVA.mCherry (UNC Vector Core; Watabe-Uchida et al., 2012) and AAV9.Flex.H2B. GFP.2A.oG (Salk Gene Transfer, Targeting and Therapeutics Core; Kim et al., 2016) were injected unilaterally into the interposed nucleus of Ntsr1-Cre and Gad1-Cre mice. After a 6 week incubation, a third injection of EnvA.SAD $\Delta$ G.eGFP virus was made into the same interposed nucleus (Salk Gene Transfer, Targeting and Therapeutics Core; Wickersham et al., 2007; Wall et al., 2010; Kim et al., 2016). Mice were killed after an additional week and prepared for histological examination.

\section{Tissue preparation for light microscopy}

Mice were overdosed with an intraperitoneal injection of a sodium pentobarbital solution, Fatal Plus (Vortech Pharmaceuticals), and perfused transcardially with $0.9 \%$ saline followed by $4 \%$ paraformaldehyde. Brains and spinal cords were removed and postfixed for at least $24 \mathrm{~h}$ then cryoprotected in $30 \%$ sucrose. Tissue was sliced in $40 \mu \mathrm{m}$ serial coronal sections using a freezing microtome and stored in $0.1 \mathrm{M}$ PB.

\section{Immunohistochemistry}

Floating sections spanning the cerebellum to midbrain were rinsed in a permeabilization solution to increase tissue penetration ( $1 \mathrm{~h} ; 0.1 \mathrm{M} \mathrm{PB}$, $0.15 \mathrm{M} \mathrm{NaCl}, 0.3 \%$ Triton X-100, and $1 \%$ bovine serum Albumin). To visualize $\mathrm{BDA}$, sections were incubated with streptavidin conjugated to AlexaFluor 488 or 555 (Life Technologies) diluted 1:100 in 0.1 м PB for 
$2 \mathrm{~h}$ followed by three washes in PB (10 min each). Mounted sections were coverslipped and mounted in Fluoromount-G (SouthernBiotech). Tissue processed for Nissl was incubated in a 1:500 dilution of Neurotrace Fluorescent Nissl stain (Life Technologies) for $20 \mathrm{~min}$ followed by a 10 min rinse in $\mathrm{PB}$ with $0.3 \%$ Triton $\mathrm{X}$.

\section{Imaging}

Confocal images of immunolabeled sections were obtained using either a Zeiss Axioskop 2 running LSM5 Pascal or a Zeiss Observer.Z1 3i Marianas Spinning Disk microscope equipped with an Evolve camera running Slidebook software (Intelligent Innovations). Pixel intensity histograms were adjusted using ImageJ.

To quantify innervation of the IN relative to the cerebellar cortex for $\operatorname{RNm}(n=3)$ and basilar pontine nuclei $(n=3)$, we imaged five representative cerebellar sections along the anterior-posterior axis (from bregma: $-6.96,-6.64,-6.36,-6.00,-5.88 \mathrm{~mm}$ ) for mossy fiber rosette (MFR) analysis in the granule cell layer (GCL) and three representative sections for IN (from bregma: $-6.64,-6.36,-6.00 \mathrm{~mm}$ ). Montage images of the entire cerebellar cortex within a section ( $4 \mu \mathrm{m}$ stacks) were collected on a spinning disc confocal microscope, with a $40 \times$ objective. All imaged MFRs in the GCL and boutons in the IN were counted and mapped in ImageJ. We measured imaged areas in MATLAB to compute imaged volume. The density of rosettes and boutons was computed from the total counts normalized to the volume of each imaged stack for GCL and IN independently. We estimated the total volume of the GCL and IN-containing boutons by multiplying average areas of adjacent samples with the distance between samples. Total MFRs and boutons were then estimated using average density measurements and the estimated volume.

\section{Electrophysiology}

Virus injections. Before recording, C57BL/6 mice (1-2 months old) were injected with AAV1.hSyn1.ChR2(H134R).mCherry bilaterally in either the IN or RNm using the coordinates described for anatomical tracing. Mice were used after 6-8 weeks to allow expression strong enough to be detected in distal structures.

Slice preparation. Animals were sedated with isoflurane before perfusion. Animals were perfused with cold $\left(0-2^{\circ}\right)$ oxygenated $(95 \%$ $\mathrm{O}_{2}-5 \% \mathrm{CO}_{2}$ ) sucrose cutting solution containing the following (in $\mathrm{mM}$ ): $2.5 \mathrm{KCl}, 1.25 \mathrm{NaH}_{2} \mathrm{PO}_{4}, 25 \mathrm{NaHCO}_{3}, 7$ dextrose, $1.3 \mathrm{Na}$-(L) ascorbate, $3 \mathrm{Na}$-pyruvate, 210 sucrose, $7 \mathrm{MgCl}_{2}$, and $0.5 \mathrm{CaCl}_{2}$. Sections $(300 \mu \mathrm{m})$ of either cerebellum or red nucleus were cut in the coronal plane on a Leica Z1000 Vibratome. Tissue was then transferred to an oxygenated holding solution $\left(37^{\circ}\right)$ containing the following (in $\mathrm{mm}$ ): $125 \mathrm{NaCl}, 2.5$ $\mathrm{KCl}, 1.25 \mathrm{NaH}_{2} \mathrm{PO}_{4}, 25 \mathrm{NaHCO}_{3}, 2 \mathrm{CaCl}_{2}, 2 \mathrm{MgCl}_{2}, 10$ dextrose, $1.3 \mathrm{Na}$ L-ascorbate, and $3 \mathrm{Na}$ L-pyruvate.

In vitro recordings. Forty-five to $60 \mathrm{~min}$ after slicing, tissue was transferred to the recording chamber. Oxygenated Tyrodes solution was perfused over the slice at $3 \mathrm{ml} / \mathrm{min}$ and contained the following (in $\mathrm{mM}$ ): 125 $\mathrm{NaCl}, 2.5 \mathrm{KCl}, 1.25 \mathrm{NaH}_{2} \mathrm{PO}_{4}, 25 \mathrm{NaHCO}_{3}, 1.5 \mathrm{CaCl}_{2}, 1 \mathrm{MgCl}_{2}$, and 12.5 dextrose. In $\mathrm{RNm}$ recordings only, extracellular solution was supplemented with 3 sodium L-pyruvate (Zhao et al., 2011). Slices were perfused with warmed $\left(30^{\circ} \mathrm{C}\right)$ solution and visualized with a Zeiss AxioExaminer equipped with an LED system for optogenetic stimulation through the objective (CoolLED). Axons were stimulated optogenetically with 1-2 ms light pulses with a measured power of $15.5 \mathrm{~mW}(0.96$ $\mathrm{mW} / \mathrm{mm}^{2}$ ) at $473 \mathrm{~nm}$. Axons were electrically stimulated with a concentric bipolar stimulating electrode (FHC) connected to an Iso-Flex stimulation isolation unit $(0.1 \mathrm{~ms}$ stimulus duration; 0.5-3 V). Pulled glass patch electrodes (2-3.5 M $\Omega$; Sutter Instruments, P-97) were filled with either K-gluconate based internal solutions or $\mathrm{Cs}^{+}$-based internal solutions. K-gluconate-based internal solution contained the following (in mM): $130 \mathrm{~K}$-gluconate, $2 \mathrm{Na}$-gluconate, $4 \mathrm{NaCl}, 2 \mathrm{MgCl}_{2}, 1$ EGTA, 10 HEPES, 4 sucrose, 14 TRIS creatine phosphate, $4 \mathrm{Mg}$-ATP, and $0.3 \mathrm{Mg}$ GTP. Recordings done with $\mathrm{Cs}^{+}$-based internal solution contained the following (in mM): 125 Cs-methanesulfonate, 10 HEPES, 0.5 EGTA, 8 $\mathrm{NaCl}, 10 \mathrm{Na}$-phosphocreatine, $1 \mathrm{QX}-314,4 \mathrm{Mg}$-ATP, and 0.4 Na-GTP. Whole-cell recordings were made in current-clamp and voltage-clamp mode, low-pass filtered at $6 \mathrm{kHz}$, and amplified with a MultiClamp 700B,
A
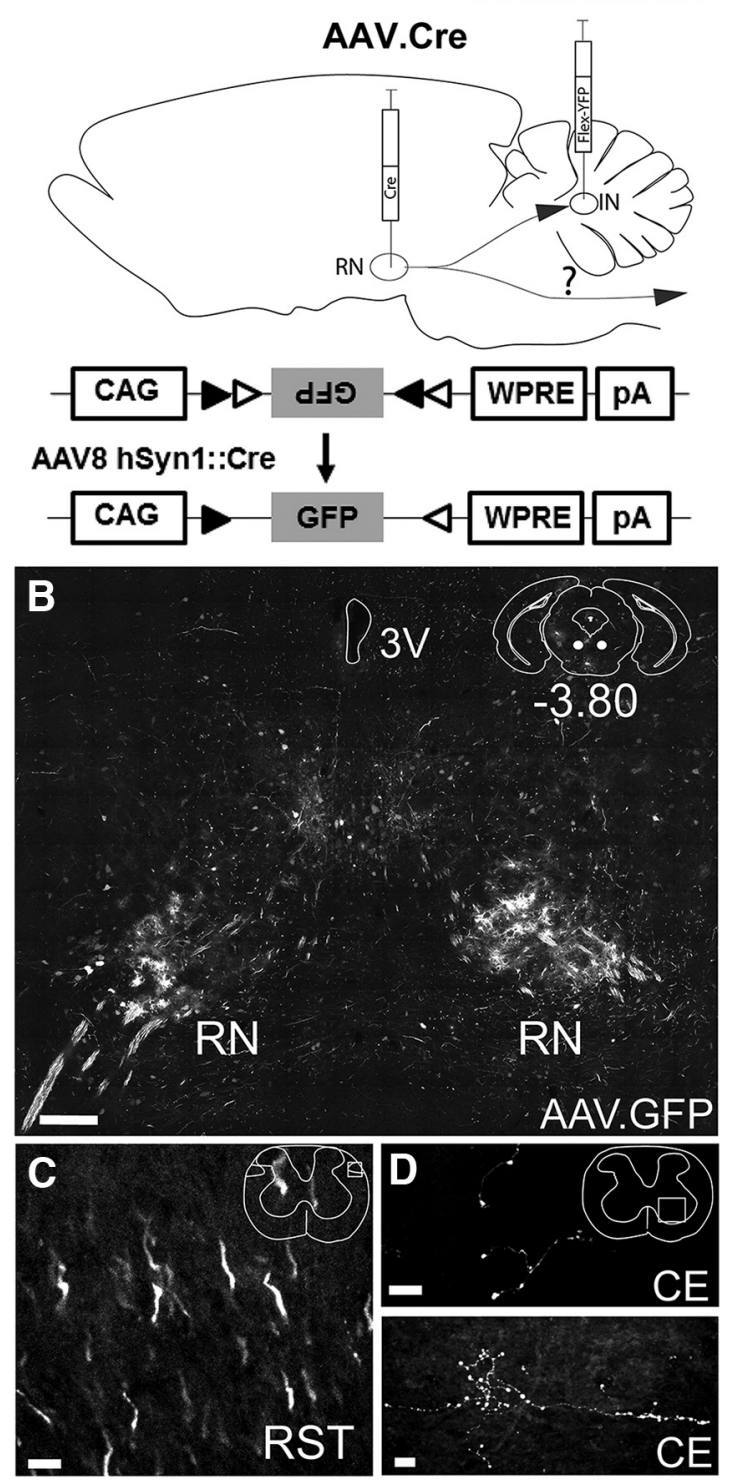

Figure 1. The rubrospinal tract collateralizes to the interposed nucleus. $\boldsymbol{A}$, Schematic of experiment. The cre-expressing virus AAV8.hSyn1.mCherry. Cre was injected into the RN and a Cre-dependent retrogradely transported virus, AAV1.CAG.Flex.eGFP, was injected into the IN to label IN-projecting neurons in the RN. $\boldsymbol{B}$, Example coronal section showing GFP expression in the $\mathrm{RNm}(-3.80 \mathrm{~mm}$ from bregma; $n=7)$. Scale bar, $200 \mu \mathrm{m}$. C, GFP-expressing axons in the rubrospinal tract at $C 5$ level of the spinal cord. Scale bar, $10 \mu \mathrm{m}$. $\boldsymbol{D}$, GFP-expressing axon terminals in the ventral horn gray matter at the $\mathrm{C} 5-\mathrm{C} 7$ level $(n=4)$. Scale bar, $10 \mu \mathrm{m}$. RST, Rubrospinal tract; $\mathrm{CE}$, cervical enlargement; $3 \mathrm{~V}$, third ventricle.

partially compensated for series resistance, digitized at $10-20 \mathrm{kHz}$ with a Digidata 1440A digitizer and acquired with pClamp acquisition software (Molecular Devices). Blockade of neurotransmitter receptors was achieved with bath application of $10 \mu \mathrm{M}$ RS-CPP (Tocris Bioscience) for NMDAR-mediated currents, $10 \mu \mathrm{M}$ DNQX (Tocris Bioscience) for AMPAR-mediated currents, and $10 \mu \mathrm{M}$ SR95531 (Tocris Bioscience) for $\mathrm{GABA}_{\mathrm{A}} \mathrm{R}$-mediated currents. Data were analyzed with custom routines and the Neuromatic package (ThinkRandom) in IGOR Pro (Wavemetrics). For analysis of tonic excitatory currents, the difference between total current and the phasic current, computed relative to the average baseline current $1 \mathrm{~ms}$ before each stimulus pulse, was calculated.

\section{Experimental design and statistics}

The present study was designed to investigate the organization and functional properties of the anatomical loop between the RNm and 
IN. Anatomical observations include between three and six specimen to ensure reliability of innervation patterns. Physiological observations that involved paired $t$ tests were used; normality requirements were followed and were performed in Excel. Within sample $t$ tests comparing baseline firing rate and stimulus response rate were used to determine responsivity to stimulus trains and included at least 10 observations per cell (see Fig. 4). Regression analysis was performed relating measured tonic current with firing rate changes in IN neurons.

\section{Results}

Rubrospinal tract provides corollary discharge information to the cerebellum Cerebellar internal model computations are hypothesized to require corollary discharge (CD), carried via mossy fibers. One potential source of this information is spinal-projecting premotor neurons such as those in RNm. Indeed, a previous report using dual retrograde tracing from the cerebellum and spinal cord suggested that rubrospinal neurons collateralize to innervate the cerebellar nuclei (Huisman et al., 1983). To study the cellular composition of this pathway, we used a dual virus labeling strategy that, as opposed to more widely used retrograde tracing methods, permitted specific visualization of projection patterns of IN-projecting RNm neurons. To achieve this specificity, we injected a Cre-expressing virus into the $\mathrm{RNm}$ and a retrogradely transported Credependent reporter virus into the IN (Fig. $1 A)$. We had previously shown retrograde capacity of AAV1.CAG.Flex.eGFP (Houck and Person, 2015) and therefore injected it into the IN along with AAV8.hSyn1. mCherry.Cre into the RNm of wild-type mice $(n=8)$. We anticipated this method would selectively label Cre-expressing RNm neurons projecting to the IN. As expected, following a 2-4 week survival time, cells in the RNm expressed GFP, corroborating previous observations of the RNm projection to the IN (Fig. 1B). We next examined whether and where IN-projecting RNm cells terminated in the spinal cord. Coronal sections of rostral spinal cord extending through the cervical enlargement (C1-C7 levels) revealed axons in the rubrospinal tract expressing robust GFP (Fig. $1 C)$. Labeled rubrospinal axons coursed through the cervical enlargement where they ramified in the gray matter (Fig. $1 D ; n=3$ ). These observations confirm previous findings from Huisman et al. (1983) that RNm rubrospinal neurons collateralize to innervate the interposed nucleus of the cerebellum, providing a likely source of CD information.

Consistent with the notion that IN-projecting RNm neurons were rubrospinal neurons, the somata of labeled $\mathrm{RNm}$ neurons were large, with an average diameter of $23.0 \pm 5.2 \mu \mathrm{m}(n=48$ cells, 4 animals). Cell size ranged from 14.9 to $40.1 \mu \mathrm{m}$, typical of the range of cell sizes that exist in the spinal-projecting region of the RNm (Reid et al., 1975). Although somata were labeled
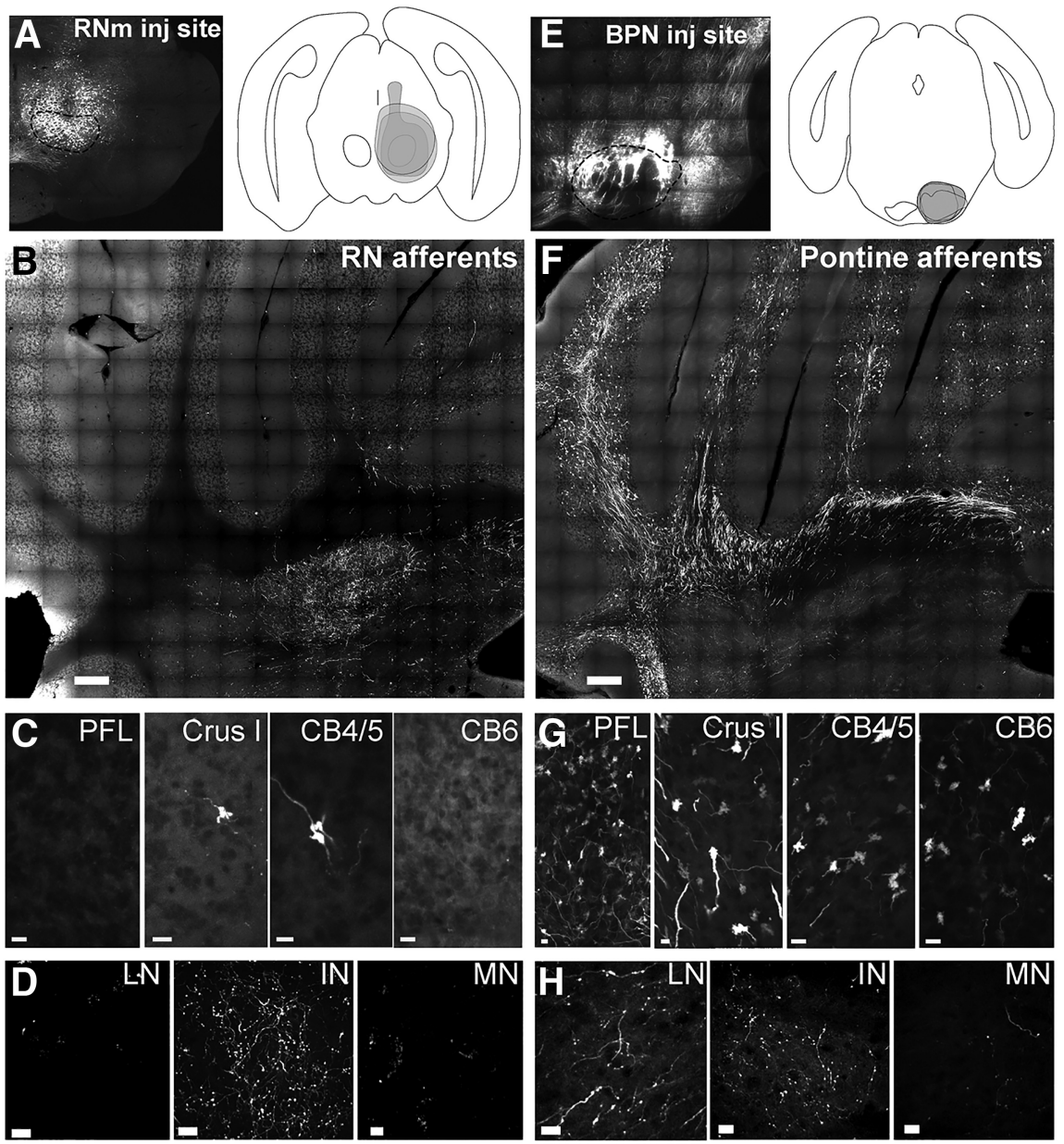

Figure 2. Preferential targeting of IN by the rubrocerebellar pathway. $\boldsymbol{A}$, Representative injection of AAV.hSyn.eYFP into RNm. Overlaid RN injection sites are mapped. $\boldsymbol{B}$, Representative coronal section of the cerebellum following AAV1.hSyn1.eYFP injection into the RNm. Dense terminal labeling is restricted to the IN with very sparse MFR label in the cortex $(n=3)$. Scale, 200 microns. bar, $5 \mu \mathrm{m}$. D. Representative example of lateral, interposed, and medial nucleus after AAV injection into RNm Scale bar, $10 \mu \mathrm{m}$ resentative injection of AAV.hSyn.eYFP into BPN. Overlaid BPN injection sites are mapped. $F$, Representative coronal section few terminals in the interposed nuclei $(n=3)$ Scale 200 microns. G. Higher magnification images of paraflocculous, Crus 1 , cerebellar cortical lobules $4 / 5$ and 6, after AAV injections into BPN. Scale bar, $5 \mu \mathrm{m}$. $\boldsymbol{H}$, Representative example of lateral, interposed, and medial nucleus after AAV injection into BPN. Scale bar, $10 \mu \mathrm{m}$. INb, Interposed nucleus boutons; PFL, paraflocculus; CB6, cerebellar cortex 6; LN, lateral nucleus; MN, medial nucleus; CB4/5, cerebellar cortex 4/5.

throughout the rostral-caudal extent of RNm, they did not appear in the parvocellular RN (RNp), as indicated by Nissl staining, which helped delineate RNm from surrounding regions. Together, these data confirm that RNm projects to the cerebellum via premotor rubrospinal axon collaterals.

\section{Preferential targeting of IN by the rubrocerebellar pathway}

A majority of excitatory afferents to the IN are assumed to be collaterals of mossy fibers (Chan-Palay, 1977), suggesting that the rubrocerebellar pathway might carry $\mathrm{CD}$ information to the cerebellar cortex as well as IN. To investigate this idea, we injected RNm directly with AAV1.hSyn1.mCherry (Fig. 2A), to anterogradely label of the rubrocerebellar pathway. Interestingly, RNm afferents almost exclusively targeted IN, with very few mossy fibers in the cerebellar cortex (Figs. $2 B-D, 3 A$ ) and very little innervation of other cerebellar nuclei (Figs. $2 B-D, 3 A$ ).

To contrast this innervation pattern with another known source of mossy fibers carrying motor information, we injected 
A

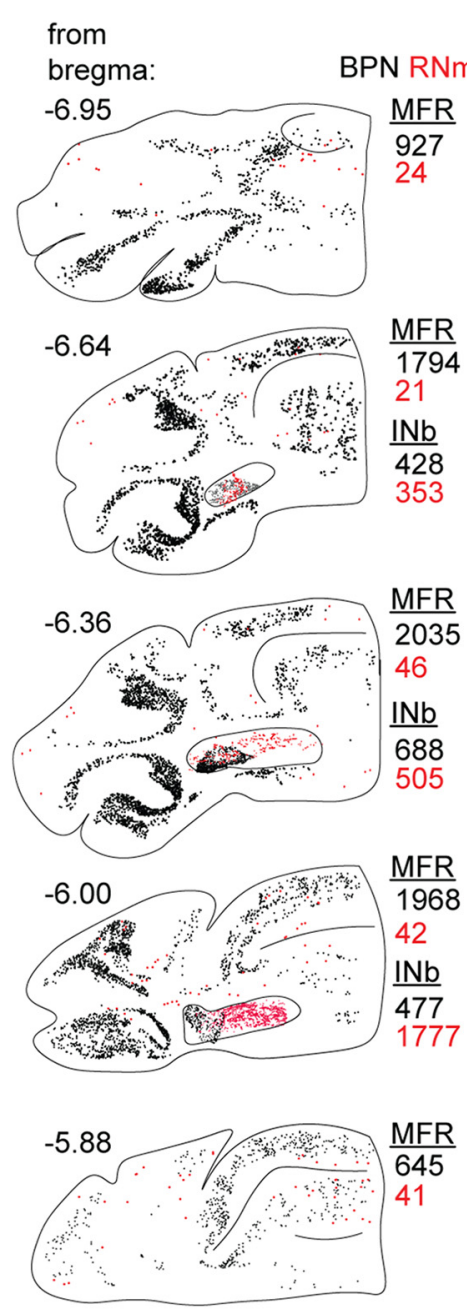

B

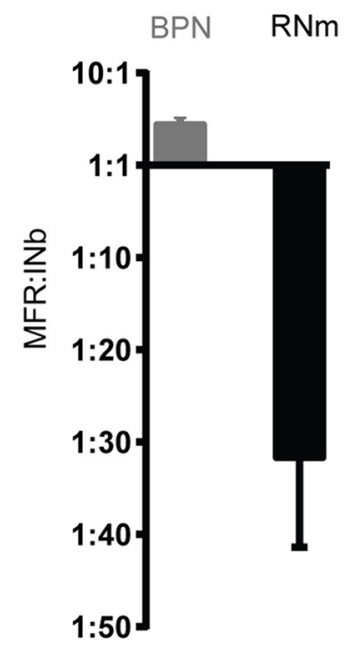

C

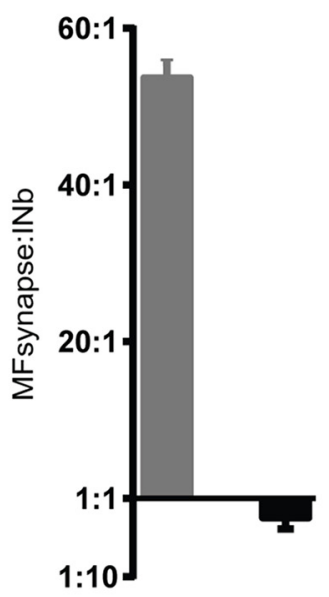

Figure 3. Quantification of differential RNm and BPN innervation of cerebellar cortex and nuclei. $\boldsymbol{A}$, Mapped MFRs and INb following injections into either BPN (black) or RNm (red). MFR and $\mathrm{INb}$ were mapped in five sections through a $1.1 \mathrm{~mm}$ anterior-posterior extent of the cerebellum and scaled based on calculated volume of either the cerebellar cortex or nuclei. $\boldsymbol{B}$, Ratio of the scaled cortical MFRs to INb following BPN injections (gray; $n=3$ ) and RNm injections (black; $n=3$ ) were calculated. BPN produced (avg \pm SEM) $4.8 \pm 0.2$ MFR for every one INb; RNm produced 31.8 \pm 9.6 INb for every one MFR. C, Synaptic innervation ratio plotted for BPN and RNm afferents considering every MFR makes conservatively 12 synapses. Calculated BPN synaptic ratio was $53.8 \pm 1.8 \mathrm{MF}$ synapses for every one INb. Calculated RNm synaptic ratio was $2.6 \pm 0.8 \mathrm{INb}$ for every one MF synapse. INb, interposed nucleus boutons.

the basilar pontine nuclei (BPN; Fig. 2E) and traced fibers to the cerebellum. Consistent with many previous reports, the pontine nuclei densely ramified in the cerebellar cortex, producing vast numbers of MFRs (Figs. 2F, G, 3; Gerrits and Voogd, 1987; Brodal and Bjaalie, 1992; Shinoda et al., 1992; Huang et al., 2013). As expected from the view that mossy fibers collateralize to the cerebellar nuclei, terminal boutons were consistently seen in the IN, as well as lateral and medial nuclei (Fig. $2 H$ ).

We next quantified the number and density of axonal endings in the IN and throughout the cerebellar cortex following RNm and BPN injections, mapping every MFR and IN bouton from three injections along a $1.1 \mathrm{~mm}$ anterior-posterior extent of the entire cerebellar hemisphere contralateral to the injection site. The cortical regions quantified included Crus I, Crus II, simple, paramedian, flocculus, paraflocculus, and lobules 1-10. Data are plotted for representative cases in Figure $3 A$. We did not

observe any clear topography of RNm MFRs in the cerebellar cortex in the areas we quantified, with isolated rosettes appearing in lobules 2-6, 8, Crus I, Crus II, and simple. We observed no deviation from this extreme sparseness beyond the cortical range quantified, accounting for the entirety of the cerebellar cortex.

Within the IN, RNm afferents produced more boutons than $\mathrm{BPN}$, despite comparable estimates of the fraction of the structure injected ( $>90 \% \mathrm{BPN},>90 \% \mathrm{RNm}$; Fig. 3). In the sampled volume (three $40 \mu \mathrm{m}$ sections spanning the anterior-posterior extent of the IN), we counted $4466 \pm 3794$ boutons following $\mathrm{RNm}$ injections (SD; $n=3$ ), whereas the same volume of IN contained just $1881 \pm 1377$ labeled boutons following BPN injections (SD; $n=3)$. By contrast, BPN injections labeled $10,611 \pm 3710$ MFRs (SD; $n=3$ ), in the sampled volume (five 40 $\mu \mathrm{m}$ sections spanning $1.1 \mathrm{~mm}$ anterior-posterior) within the cerebellar cortex, whereas RNm injections labeled only $124 \pm 65$ $(\mathrm{SD} ; n=3)$.

To further characterize this differential targeting, we computed the "innervation ratio" describing the relative input to the IN vs the cerebellar cortex (Fig. $3 B, C$; see Materials and Methods). Briefly, we computed the density of MFRs or boutons counted in the GCL and IN, respectively, then scaled these values to the total volume of these structures to estimate the total number of MFRs and boutons labeled. Using this method, RNm afferents produced an estimated $31.8 \pm 9.6$ boutons in IN for every 1 MFR (Fig. 3B, black bar). Conversely, BPN afferents produced $\sim 1$ IN bouton for every $4.8 \pm 0.2$ MFRs (Fig. $3 B$, gray bars; $n=$ 3 ). To account for the fact that MFRs make conservatively $\sim 12$ synapses per rosette, we calculated the synaptic innervation ratio weighted for the synaptic density of mossy fiber rosettes. Even taking into account multiple synapses per rosette, RNm afferents produced more synapses in the IN compared with the cerebellar cortex (synaptic innervation ratio, $2.6 \pm 0.8 \mathrm{IN}$ boutons for every MF synapse; Fig. $3 C$, black bar; $n=3$ ). Not surprisingly, the dominance of BPN input to the cortex was augmented, with $\sim 53.8 \pm 1.8 \mathrm{MF}$ synapses/IN bouton (Fig. $3 C$, gray bar; $n=3$ ). These findings reveal that precerebellar afferents differentially target the cerebellar cortex and cerebellar nuclei.

\section{Red nucleus afferents contact both inhibitory and excitatory cells in the cerebellar nuclei}

To address the potential role of rubrocerebellar afferents to the IN, we examined which cell types within the IN are contacted by the pathway. We used G-deleted rabies virus targeted to specific cell types under the control of Cre-recombinase (EnvA.SAD $\Delta \mathrm{G}$. eGFP; Wickersham et al., 2007; Wall et al., 2010). This method restricts transsynaptic retrograde label to presynaptic partners of Cre-expressing neurons (Fig. 4A). To identify presynaptic partners of premotor excitatory output neurons in the IN, we used Ntsr1-Cre gn220 transgenic mice, as previously characterized (Houck and Person, 2015). To identify presynaptic partners of GABAergic IN neurons, we used Gad1-Cre transgenic mice (Higo et al., 2009). We expressed Cre-dependent avian glycoprotein EnvA receptor, TVA, and the optimized glycoprotein (oG) required for rabies transsynaptic infection with injections of AAV1.Flex.TVA.mCherry and AAV9.Flex.H2B.GFP.2A.oG into either Ntsr1-Cre or Gad1-Cre mice (Fig. 4B,D). TVA.mCherry as well as nuclear GFP in oG-expressing cells was observed in the IN of Ntsr1-Cre (Fig. $4 B, C, F ; n=7)$ and Gad1-Cre mice $(n=4$; Fig. $4 D-F)$. Although the density of putative starter cells differed between preparations, we observed strong eGFP expression in somata and dendrites following injections in both transgenic mouse lines, indicative of rubrocerebellar afferents synapsing on 
both cell types (Fig. 4F; $n=4 / 4$ Gad1-Cre; $n=1 / 7$ Ntsr1-Cre). The efficacy of Credriven expression of TVA and oG differed between the mouse lines and between specimen precluding meaningful quantitative comparisons of retrograde label. However, retrograde label in $\mathrm{RNm}$ is mapped for representative cases illustrating the range of label observed following injections into the IN (Fig. $4 F$ ) illustrating the distribution of labeled neurons throughout the anterior-posterior extent of $\mathrm{RNm}$. Together, these results indicate that the rubrocerebellar pathway contacts diverse cell types within the IN.

\section{Physiological properties of}

rubrocerebellar afferents

Excitatory afferents to the cerebellar nuclei are in an important position to modulate responses to inhibitory Purkinje neurons, which also converge in the nuclei. Because RNm afferents targeted the IN specifically, we used optogenetics to specifically target and manipulate RNm terminal activity within the IN asking whether these inputs could modulate IN output directly. A cell-filling construct AAV1.hSyn1.ChR2.mCherry was injected into the RNm 6 weeks before recording. We recorded from 73 adult IN neurons in the vicinity of mCherry-expressing fibers in whole-cell and cell-attached modes (Fig. 5), and observed light-evoked responses in a minority of them $(n=17)$.

In whole-cell, voltage-clamp mode, short-latency $(1.3 \pm 0.2 \mathrm{~ms}$ from pulse onset) light-evoked EPSCs averaged $16.9 \pm$ $3.5 \mathrm{pA}(n=12)$ on the first pulse. EPSCs were sensitive to glutamate receptor antagonists DNQX and CPP $(10 \mu \mathrm{M})$, reducing amplitudes by $78.9 \pm 3.8 \%$ of control (Fig. $5 B ; n=6$ ). In a majority of cells, trains of light pulses at 20 or $50 \mathrm{~Hz}$ evoked EPSCs that facilitated $(n=8 / 12)$, reaching $152 \pm 20 \%$ of the initial amplitude by pulse 10 . In the remaining four neurons, EPSCs depressed to $58 \pm 14 \%$ of their initial amplitude (Fig. 5C,D; $n=4 / 12$ ). We also noted diversity in the amount of tonic excitatory current (current that does not fully decay between stimuli) that developed over the course of a $50 \mathrm{~Hz}$ train, which accounted for an average of $23.4 \pm$ $5.6 \%$ of the total current by the end of the train (range, $7.0-61.4 \%$ ). To relate these observations of synaptic properties to the capacity of the afferent to drive activity in IN neurons, we delivered trains of light stimuli in current-clamp mode or in the cell-attached configuration. In neurons that showed a significant response to $50 \mathrm{~Hz}$ trains of light pulses, firing rates increased an average of $12.3 \pm 5.2 \%, n=12$, but showed a wide range of responsivity, ranging from increases between

A
AAV-FLEX-TVAmCherry

AAV-FLEX-H2B-GFP-2A-OG

Rabies virus

(EnVA-SAD $\Delta$ G-EGFP)

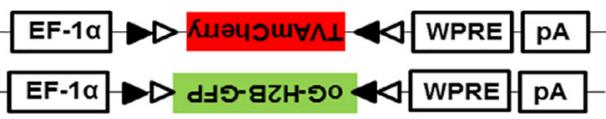

$\because$ EGFP

$\downarrow$

Interposed nucleus of GAD1::Cre orNtsr1::Cre
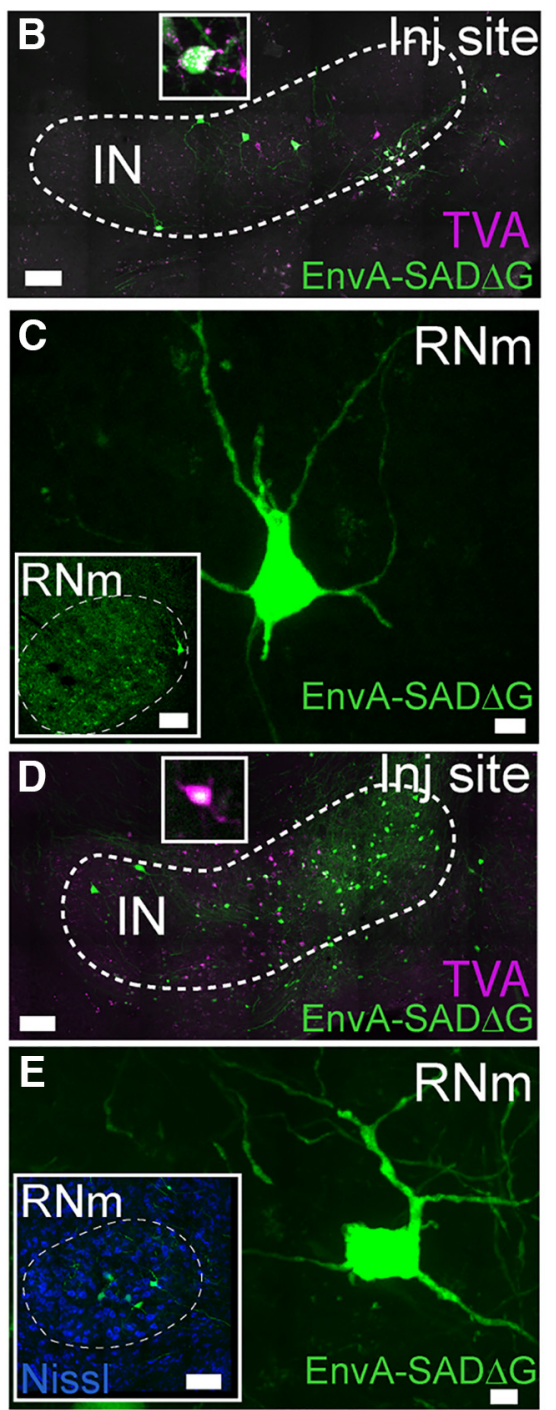

Figure 4. Rubrocerebellar pathway contacts multiple cell types in IN. $A$, Schematic of monosynaptic rabies viral tracing strategy illustrating coinjection of AAV1.Flex.TVA.mCherry and AAV9.Flex.H2b.GFP.2A.0G into the IN. Following 6 weeks for expression, EnvA.SAD $\Delta$ G.eGFP was also injected into the IN. $\boldsymbol{B}$, IN injection site demonstrating sparse label of both TVA and EnvA.SAD $\Delta$ G.eGFP in Ntsr1-Cre mouse. Inset, Neuron colabeled with TVA-mCherry and eGFP $(n=7)$. Scale bar, $100 \mu \mathrm{m}$. C, High-magnification image of transsynaptic retrograde label in RNm. Scale bar, $10 \mu \mathrm{m}$. Inset, Low-power image of RNm. Scale bar, $100 \mu \mathrm{m}$. D, IN injection site demonstrating sparse label of both TVA and EnvA.SAD $\Delta$ G.eGFP in Gad1-Cre animal $(n=4)$. Inset, Neuron colabeled with TVA$\mathrm{mCherry}$ and eGFP. Scale bar, $100 \mu \mathrm{m}$. $\boldsymbol{E}$, High-magnification image of trans-synaptic retrograde label in RNm. Scale bar, $10 \mu \mathrm{m}$. Inset, Low-power image of RNm counterstained with Nissl. Scale bar, $100 \mu \mathrm{m}$. F, Map of retrograde label illustrating range of label observed in Gad1-Cre (blue and black) and Ntsr1-Cre mice (red).

$1.3 \%$ to $67 \%$ (Fig. $5 E, F ; p<0.05$ paired $t$ test for individual cells).

We were curious whether synaptic properties could be linked to the capacity of the input to drive firing and reasoned that the tonic current that developed in some neurons might account for increased excitatory drive, as has been shown in dynamic clamp 
A
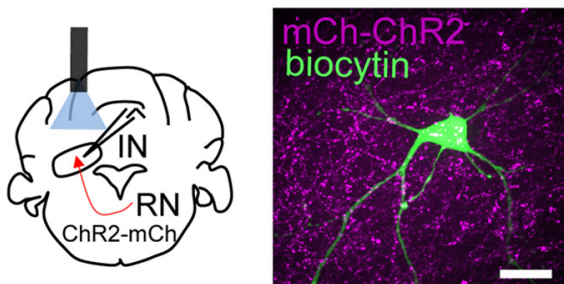

C

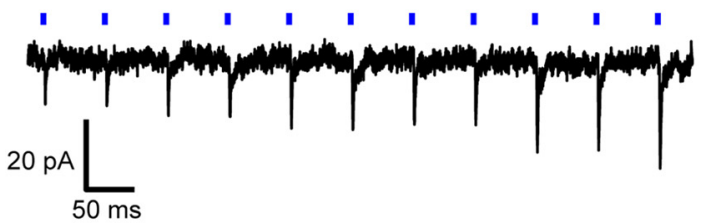

E

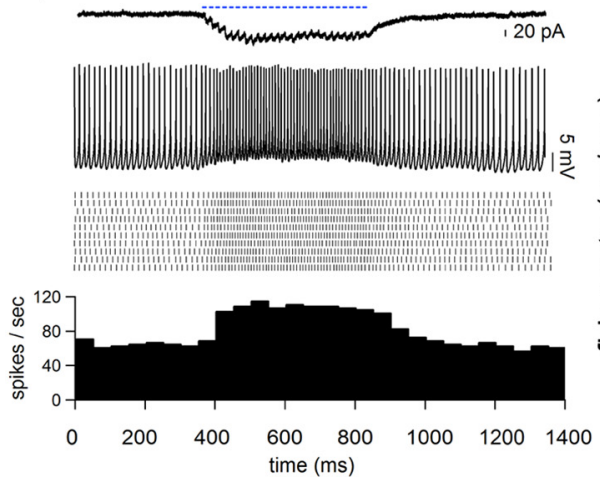

B

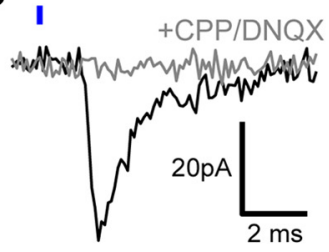

D

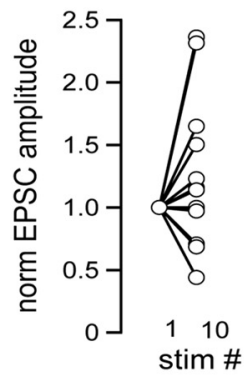

G

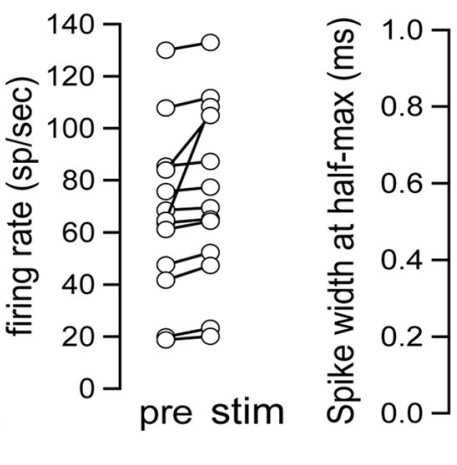

$\infty$

Figure 5. Electrophysiological properties of rubrocerebellar pathway. A, Schematic of recording strategy in coronal section of the cerebellum following AAV1.ChR2.mCherry injection into RNm. Cell filled with biocytin after recording surrounded by mCherryexpressing RNm terminals. Scale bar, $20 \mu \mathrm{m}$. B, Top, Light-evoked EPSCs in an IN cell ( $-70 \mathrm{mV}$ ). Bottom, EPSCs were abolished following application of DNQX and CPP ( $10 \mu \mathrm{m}, n=6)$. Scale $20 \mathrm{pA}, 2 \mathrm{~ms}$. C, Light-evoked EPSCs at $20 \mathrm{~Hz}$. Scale, $20 \mathrm{pA}, 50 \mathrm{~ms}$. $D$, Short term facilitation of rubrocerebellar afferents. Eight of 12 recordings showed EPSC facilitation, whereas 4 of 12 showed depression. $\boldsymbol{E}$, Example cell showing light-evoked currents (top) and firing (bottom) during $50 \mathrm{~Hz}$ light stimulation. Note slow tonic current (top trace). Raster plot and PSTH summarize changes in firing rate for this cell $>10$ sweeps. Scale, 20 pA. $\boldsymbol{F}$, Summary of IN responses to light stimulation of RN afferents at $50 \mathrm{~Hz}$ in current-clamp. Fifty hertz stimulation increased average firing rates by $12.3 \pm 5.2 \%$ with a range of responses from $1.3 \%$ to $67 \%$ over baseline ( $p<0.05$ paired $t$ test for individual cells, $n=12$ ). $G$, Spike-width at half-maximum in neurons receiving rubrocerebellar input and recorded in whole-cell current-clamp mode.

$0.8 \mathrm{~ms}$ (Fig. 5G), with most neurons possessing brief spikes (10/12) typical of large putative excitatory neurons, and a small minority with broader spikes $(>0.6$ $\mathrm{ms})$, characteristic of nucleo-olivary neurons (2/12).

\section{IN afferents to the RNm target areas} with few inhibitory neurons

The dynamics of recurrent feedback loops depend on the relative strength and organization of each side of the loop. Because the RNm is a major target of the IN, we next investigated the organization and physiological properties of IN outputs to the RNm (Fig. 6). We first asked whether anatomical characteristics of the IN-RNm pathway were suggestive of positive feedback, negative feedback or both by analyzing RNm cell types in regions targeted by IN. Posterior RNm showed a surprising paucity of inhibitory neurons, delineated with in situ hybridization for Gad1 and Gad2 (Fig. 6B; material from the Allen Brain Atlas; Lein et al., 2007; http:// mouse.brain-map.org), although Gad1and Gad2 mRNA-positive cells surrounded the periphery (Liang et al., 2012). We also examined GlyT2 expression in the RNm of GlyT2-GFP mice and found similar extreme sparseness in somatic GFP expression (Fig. $6 H ; n=3$ ).

These observations raised the question of whether IN afferents target the same areas of RNm that possessed few inhibitory somata. Dual injections of anterograde tracers (either AAV.mCherry or BDA $10 \mathrm{~K}$ ) into the IN and AAV.Flex.YFP in the RNm of Gad1-Cre mice demonstrated dense innervation of areas characterized by large somata but devoid of GABAergic cells (Fig. 6C-F; $n=5$ ). In parallel experiments, IN-RNm terminal fields innervated $\mathrm{RNm}$ regions with few if

studies in the nuclei (Gauck and Jaeger, 2003). Regression analysis supports this idea: the tonic current amplitude at the end of a $500 \mathrm{~ms} 50 \mathrm{~Hz}$ pulse train was strongly correlated with the capacity of the input to drive increases in firing rate during a $50 \mathrm{~Hz}$ stimulus train (correlation coefficient $=0.97 ; R^{2}=0.96 ; F=96.6$, $\mathrm{df}=5, n=7$ ), and better accounted for firing rate changes than phasic excitatory current $\left(R^{2}=0.61\right)$. Summation of tonic current likely accounts for the slight depolarization of the baseline during a $50 \mathrm{~Hz}$ train of the neuron shown in Figure $5 E$. These data indicate that $\mathrm{RNm}$ afferents can drive activity in IN and reveal a role for tonic excitatory current in effectively driving increases in firing rate in nuclear neurons.

Previous studies have shown that the spike width of neurons in the IN can be used to differentiate cell types (Uusisaari et al., 2007; Najac and Raman, 2015). We therefore measured the spike-width at half-maximum amplitude of all neurons in which we observed a response in whole-cell current-clamp mode. In keeping with our anatomical observations that RNm afferents contact multiple cell types, we measured spike widths from 0.2 to any GlyT2.eGFP-expressing cells (Fig. 6G-J; $n=3$ ). Instead, IN afferents produced dense nets of boutons surrounding large somata delineated with Nissl (Fig. 6E,F,I,J, right). Therefore, IN targeted areas of RNm that possessed very few inhibitory somata.

Optogenetic activation of IN afferents evoke purely excitatory response in $\mathrm{RNm}$

Although our anatomical observations suggest that IN afferents innervate areas with few if any inhibitory somata, it remained possible that dendrites of inhibitory neurons on the periphery of RNm could be contacted by IN axons and mediate feedforward inhibition within RNm (Jiang et al., 2002). Moreover, the basic properties of IN-RNm synapses are important for models of the motor system that incorporate cerebellar-brainstem communication. We therefore used optogenetic activation of the IN-RNm pathway to selectively study the influence of IN on RNm. AAV1.hSyn1.ChR2.mCherry was injected into the IN of wildtype mice (Fig. $7 A$ ). In an acute adult brain slice preparation, optical stimulation of cerebellar afferents elicited robust short- 
A
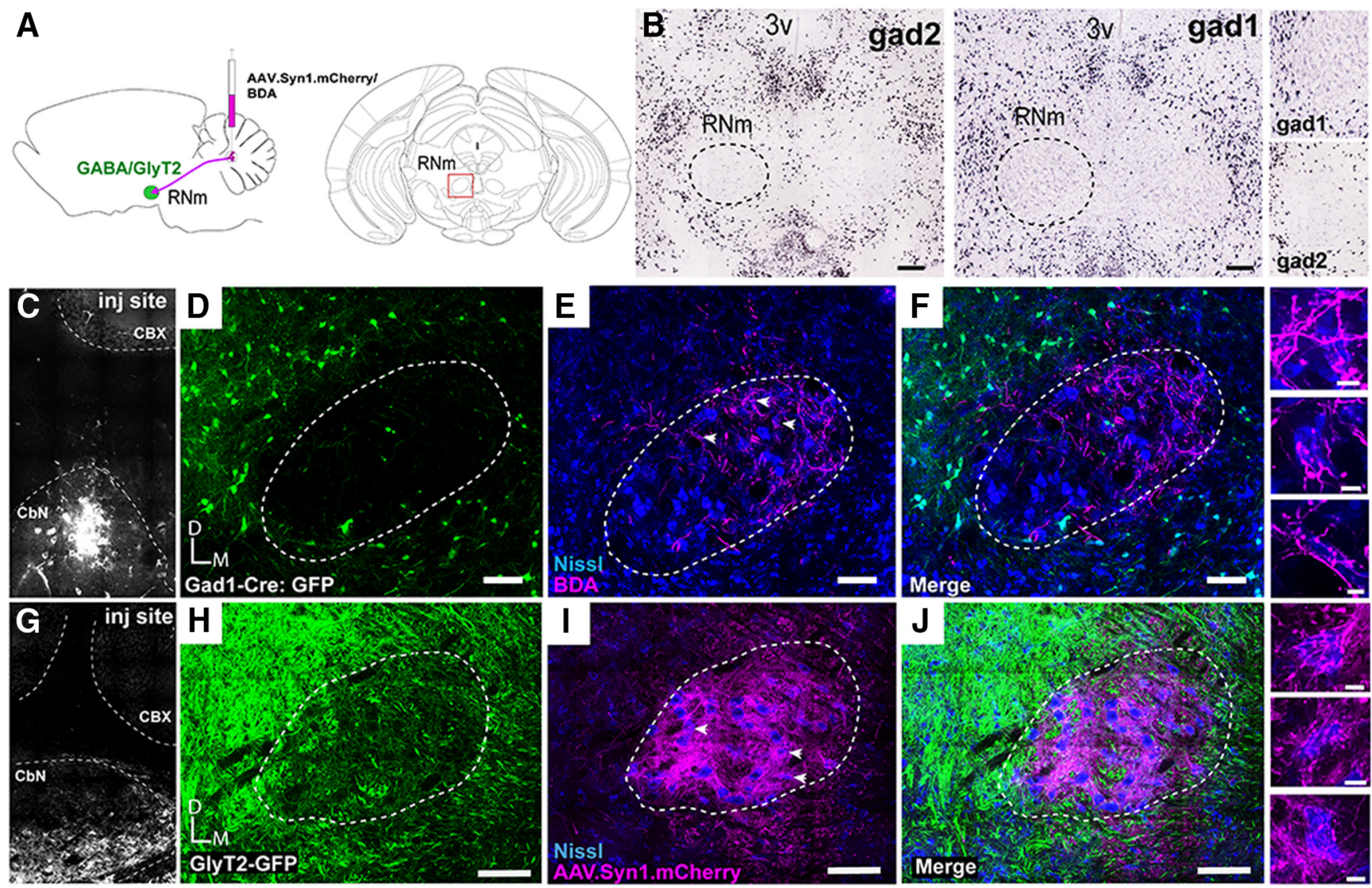

Figure 6. IN terminal fields in RNm do not overlap with inhibitory somata. $A$, Schematic of experimental setup. AAV1.mCherry or BDA 10K was injected into the IN of either Gad1-Cre or GlyT2.eGFP mice. $\boldsymbol{B}$, In situ hybridization showing Gad1 and Gad2 mRNA expression at the level of RNm from the Allen Brain Atlas (Lein et al., 2007; http://mouse.brain-map.org). Note absence of label within putative RNm. Scale bars, $200 \mu \mathrm{m}$. Right, Zoom of RNm border. C, Injection site of BDA into the Cbn of a Gad1.Cre animal, dashed line delineating CbN. $\boldsymbol{D}$, GFP-expressing cells at the level of RNm (dashed line) driven by Gad1.Cre. $\boldsymbol{E}$, BDA-labeled IN terminals in RNm, delineated with Nissl counterstain. $\boldsymbol{F}$, Merged channels from $\boldsymbol{C}$ and $\boldsymbol{D}$ showing IN terminals in area devoid of somatic Gad1-GFP label $(n=5)$. Scale bar, $100 \mu \mathrm{m}$. G, Injection site of AAV.mCherry into the CbN, dashed line. $\boldsymbol{H}$, GFP-expression in GlyT2-GFP mouse at the level of RNm (dashed line). I, mCherry labeled IN terminals target RNm, delineated with NissI counterstain (right). J, Merged channels from $\boldsymbol{H}$ and I showing IN terminals in RNm do not overlap with GlyT2-GFP somata ( $n=3$ ). Scale bar, $100 \mu m$. Right, IN terminals wrap around RNm somata counterstained with Nissl. Scale bar, $10 \mu \mathrm{m}$. CbN, Cerebellar nuclei; D, dorsal; M, medial; CBX, cerebellar cortex.

latency $(1.3 \pm 0.1 \mathrm{~ms})$ EPSCs in RNm neurons held at $-70 \mathrm{mV}$ (Fig. $7 B, D$, blue trace; $322.6 \pm 82.6 \mathrm{pA} ; n=11$; termed INEPSCs). IN-EPSCs were similar in amplitude to EPSCs elicited with electrical stimulation from unidentified dorsal afferents (Fig. 7B, C; $207.0 \pm 73.8 \mathrm{pA}$ for electrically evoked responses; $n=10$; not significantly different from IN-EPSCs, unpaired $t$ test $p=0.09$ ). Lightevoked IN-EPSCs were sensitive to application of AMPA and NMDA receptor antagonist, DNQX and CPP (Fig. $7 D ; n=10$ ).

Previous in vivo studies in anesthetized cats suggested little net short-term plasticity of the IN-RNm pathway (Toyama et al., $1968,1970)$. Using trains of light stimulation to examine shortterm plasticity of IN-RNm afferents, our data were largely in agreement. EPSCs only slightly depressed over a $20 \mathrm{~Hz}$ train of EPSCs, reaching a steady-state at $\sim 70 \%$ of the initial peak (Fig. $7 D, E$; fraction remaining \pm SEM: pulse $2,78 \pm 1 \%$, pulse 10 , $67 \pm 9 \%)$.

Whereas EPSCs elicited with light and electrical stimulation were similar, outward currents elicited at $0 \mathrm{mV}$ were not: light stimulation evoked no measureable outward currents (Fig. $7 F, G$, blue traces; $n=6$ ). By contrast, in the same cells, electrical stimulation of unidentified pathways dorsal to the RNm, consistently evoked IPSCs $(n=6 / 9)$, as has been reported previously (Schmeid et al., 1990; Fu et al., 1996). Electrically-evoked IPSCs averaged 158.2 \pm $62.2 \mathrm{pA}$, and were abolished in $10 \mu \mathrm{M}$ SR95531 (Fig. 7F, G, black traces; $n=6$ ). Our data therefore suggest that IN-RNm inputs do not readily drive feedforward inhibition of $\mathrm{RNm}$ neurons, at least at stimulus rates tested here.

Finally, we examined the capacity of IN to influence RNm firing. In current-clamp mode, IN-RNm afferent stimulation at $20 \mathrm{~Hz}$ significantly increased RNm firing rates to $20.8 \pm 1.2 \mathrm{~Hz}$ from a baseline of $10.7 \pm 3.0 \mathrm{~Hz}$ (Fig. $7 \mathrm{H}, \mathrm{I} ; p=0.03$, paired $t$ test; $n=6$ ). Thus, as expected, IN afferents readily drive RNm neurons.

\section{Discussion}

We have examined the rubrocerebellar pathway as a model of a CD pathway into the cerebellum and found that it selectively targets the IN to the near exclusion of the cerebellar cortex. In contacting diverse cell types within the IN, the RNm is in a position to modulate cerebellar nuclear integration of Purkinje inputs. Furthermore, the direct excitatory pathway from the cerebellum to the RNm, which appears nearly devoid of inhibitory neurons, suggests relatively simplified integration of cerebellar input. Our data bear interesting resemblance to circuit motifs observed in oculomotor brainstem circuitry important for neural integration of eye position signals, but occur in regions known to influence limb movement (Martin et al., 2000), raising the question of how positive feedback loops within the brainstem shown here may influence forelimb motor control (Houk et al., 1993). Additionally, we found that the RNm pathway contacts inhibitory neurons within the IN, which, based on spike-width mea- 
A

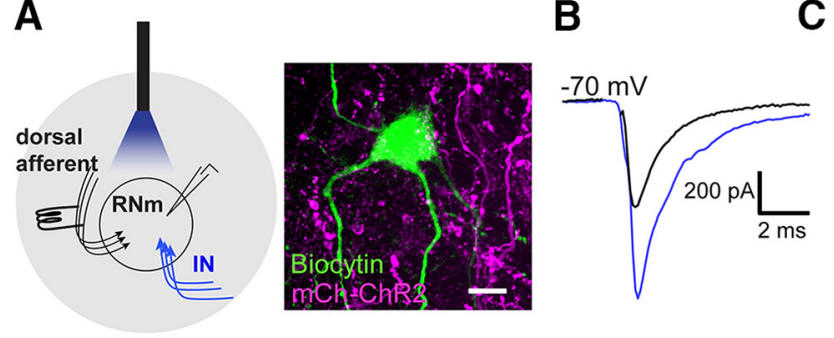

D
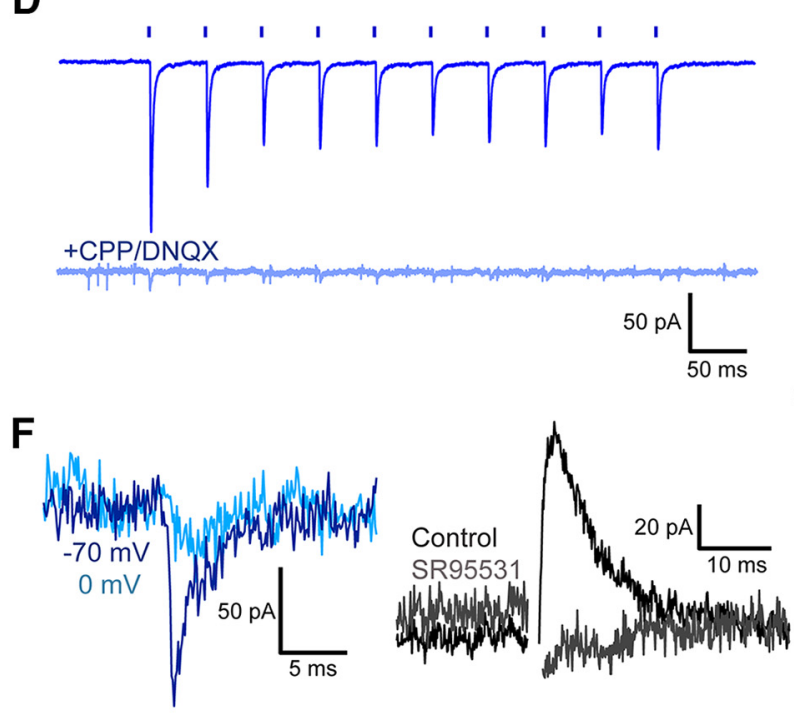

H

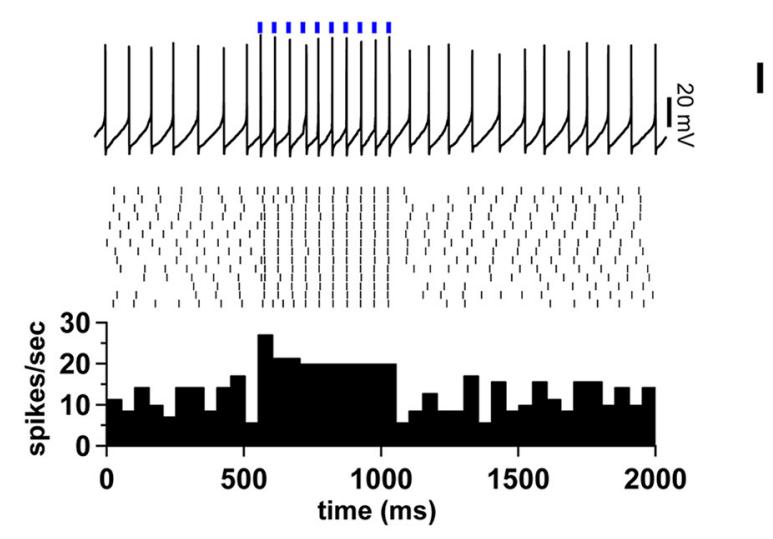

C

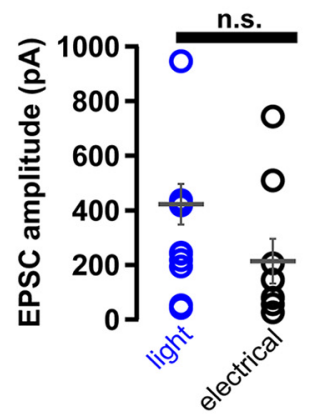

E
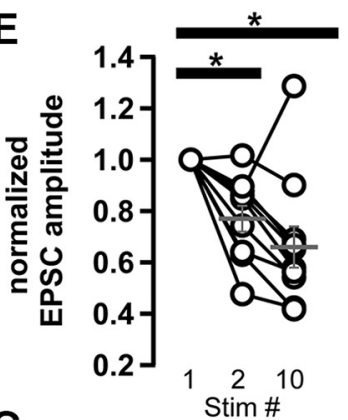

G
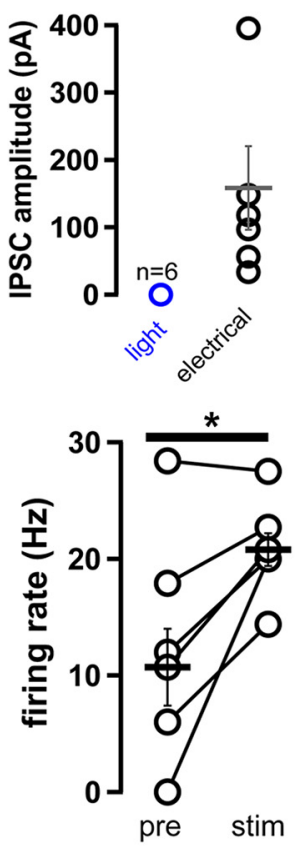

Figure 7. IN afferents to RNm evoke purely excitatory responses. $A$, Schematic of recording configuration, isolating IN afferents optogenetically and unidentified dorsal afferents electrically. Biocytin filled RNm cell surrounded by mCherry-ChR2-expressing IN terminals. $\boldsymbol{B}$, Average of light-evoked IN-EPSCs in RNm neuron (blue trace) and electrically evoked EPSCs in the same cell (black trace). C, Summary of light-evoked and electrically evoked EPSC amplitudes. Amplitudes did not differ significantly. $n=11$ light, 10 electrical; $p=0.09$, unpaired $t$ test. $\boldsymbol{D}$, Top, Light-evoked EPSCs in response to a $20 \mathrm{~Hz}$ stimulus train. Bottom, Currents were abolished in a DNQX and CPP (10 $\mu \mathrm{M})$. Scale bar, $50 \mathrm{~ms}, 50 \mathrm{pA}$. E, Summary of normalized light-evoked EPSCs over the stimulus train. EPSCs depressed $20-30 \%$ between the second and tenth pulse ( $n=10$, from pulse 1 to $2, p=0.002$; from pulse 1 to $10, p=$ 0.003 ; paired $t$ tests). $\boldsymbol{F}$, Example of light-evoked current at $-70 \mathrm{mV}$ (dark blue) and $0 \mathrm{mV}$ (light blue), along with electrically evoked outward current at $0 \mathrm{mV}$ (black) that was sensitive to application of SR95531(gray; $10 \mu \mathrm{M}$ ). G, Summary data of light-evoked (blue) and electrically-evoked (black) outward current in RNm recorded at $0 \mathrm{mV}(n=6)$. $\boldsymbol{H}$, Example trace of RNm firing before, during, and after 20 $\mathrm{Hz}$ light stimulus. Raster plot of firing and PSTH summarizing firing rate over 14 sweeps. Scale bars: top trace, $20 \mathrm{pA}$; bottom trace, 10 spikes/s. I, Summary data showing firing rate changes in RNm neurons in response to $20 \mathrm{~Hz}$ trains of light stimuli $(n=6 ; p=0.03$, paired $t$ test). Asterisks indicate $p<0.05$.

surements, could include nucleo-olivary neurons and convey information to the inferior olive.

The starkly contrasting innervation patterns of the rubrocerebellar pathway compared with the pontocerebellar pathway

challenge the common shorthand that excitatory afferents to the cerebellar nuclei are primarily collaterals of cerebellar mossy fibers (Chan-Palay, 1977). Our data support the conclusions of a recent report of nuclear-targeting precerebellar afferents from the caudal raphe interpositus area (CRI) of the median reticular formation (Fig. 8; Luo and Sugihara, 2014). While the RNm and CRI selectively target the nuclei, other mossy fiber sources studied with single cell reconstructions show the converse pattern, targeting the cerebellar cortex nearly exclusively. Neurons originating in the cuneate nucleus, for example, form MFRs but collateralize very little or not at all within any of the cerebellar nuclei (Quy et al., 2011). Finally, the lateral reticular nucleus innervates cortex and nuclei consistent with the traditional view, with single neurons collateralizing to innervate both the cerebellar nuclei as well as cerebellar cortex (Wu et al., 1999). Together, observations that the cerebellar nuclei and cerebellar cortex integrate diverse information sources raise the interesting possibility that these two structures operate as semi-independent processing hubs.

Implications of nuclear-specific afferents Both the cerebellar cortex and nuclei receive CD information. Within the cortex, this information has been suggested to be integral to forward model computations by Purkinje neurons. However, within the nuclei, the role of this information is less clear. Why might the segregated organization of different precerebellar afferents exist? One possibility is that both extracerebellar and Purkinje afferents to the nuclei produce a comparator circuit that computes sensorimotor corrections (Houk et al., 1993; Brooks and Cullen, 2009; Herzfeld and Shadmehr, 2016). Independent innervation of the cerebellar nuclei could enhance the comparator function of the circuit by allowing Purkinje activity to float relative to nuclear drive, such that an identical pattern of Purkinje activity would be integrated differently by the nuclei during movement because of increased excitatory tone from the RNm. Interestingly, Purkinje neurons show both movement-related and off-line learningrelated modulation (Hewitt et al., 2011; Popa et al., 2012, 2017), suggesting a substrate for diverse computations by the nuclei at different phases of movement and learning.

Another possibility relates to general organization of motor control circuits that frequently include positive feedback loops: notably, recurrent feedback loops in the oculomotor system produce persistent activity that helps the eye hold still during long 


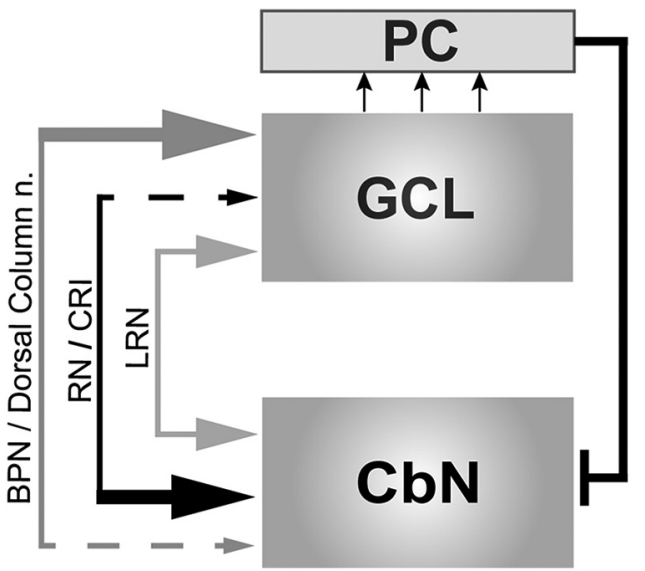

Figure 8. Summary and context of findings. A schematic diagram illustrating that diverse precerebellar regions differentially innervate the cerebellar nuclei and cerebellar cortex. The CRI and RNm preferentially target the CbN (black arrows; present study; Huisman et al., 1983; Luo and Sugihara, 2014). By contrast, the dorsal column nuclei and BPN preferentially target the cerebellar cortex (dark gray arrows; Shinoda et al., 1992; present study, Quy etal., 2011). Finally, the lateral reticular nucleus equally innervates the CbN and cortex (Wu et al., 1999).

fixations by maintaining a persistent pattern of neural activity (Anastasio and Robinson, 1989; Robinson, 1989; Seung et al., 2000; Rajan et al., 2016). Given that IN influences limb control, recurrent feedback between RNm and IN could be particularly important in maintaining both muscle recruitment when the limb is outstretched as well as supporting target kinematics over a longer time scale of limb movement (Houk et al., 1993).

Additionally, nucleo-olivary neurons within the IN have been proposed to gate plasticity induced by climbing fibers to Purkinje neurons. Contact of nucleo-olivary neurons by RNm could potentially contribute to movement-induced suppression of IO firing (Horn et al., 1998; Bengtsson and Hesslow, 2006). Two pieces of evidence suggest that this anatomical arrangement is feasible: first, we found that RNm neurons were consistently labeled following monosynaptic transsynaptic tracing with modified rabies targeted to Gad1-Cre neurons in the IN (Fig. 4; Wickersham et al., 2007; Wall et al., 2010; Kim et al., 2016). Second, we found a subset of IN neurons with long spike waveforms $(>0.6 \mathrm{~ms})$ that were responsive to optogenetic activation of RNm terminals. These long spike waveforms were recently shown to characterize nucleo-olivary neurons in mouse brain slices (Najac and Raman, 2015). Therefore, engagement of these neurons during RNminduced movement would be predicted to inhibit the IO. Future studies should address the role of this pathway on sensory gating within the IO.

\section{Anatomical and physiological features of the rubrocerebellar feedback loop}

Previous studies of the rubrocerebellar pathway concluded that RNm selectively targets the cerebellar nuclei (Huisman et al., 1983). However, evidence supporting this idea was based on retrograde tracing from the IN and cortex (Brodal and Gostad, 1954; Courville, 1968; Anderson, 1971; Huisman et al., 1981). Because the cerebellar cortex is much larger than the IN, however, negative results from cortex injections raised the objection of other investigators that came to the opposite conclusion that the RNm targeted the cerebellar cortex (Dietrichs and Walberg, 1983, 1987). Notably, anterograde tracing of the rubrocerebellar pathway had not been performed, leaving the debate unresolved. Our anterograde tracing from the RNm confirms that it heavily tar- gets the IN to the near exclusion of the cortex. Consistent with dual retrograde tracing studies, this afferent is comprised of collaterals of rubrospinal projection neurons. The method we used to test collateralization offered additional resolution of the rubrospinal axons. By restricting Cre expression to the $\mathrm{RNm}$ through a direct virus injection, then using a retrograde reporter virus injected into the IN (Houck and Person, 2015), we were able to restrict GFP expression to IN-projecting RNm neurons. GFP was readily observed in rubrospinal axons and seen in terminals invading the cervical enlargement bolstering arguments that the rubrocerebellar pathway copies premotor information involved in forelimb control (Anderson, 1971; Huisman et al., 1983).

Interestingly, although inhibitory interneurons within the IN have been recognized for decades (Chan-Palay, 1977), feedforward inhibition has only rarely been observed in physiological recordings within IN (Husson et al., 2014), suggesting that the circuitry may not be well preserved in slices. Nevertheless, it will be interesting to examine the role of the RNm feedback loop on IN output in vivo, both at the behavioral and electrophysiological level, to decipher whether its contacts onto GABAergic neurons influence premotor output when intranuclear pathways are completely preserved.

Our physiological data isolating RNm afferents in IN suggest a nuance to excitatory afferent integration by the nuclei more generally. While RNm-IN afferents produced small EPSCs, we uncovered a strong, positive correlation between tonic excitatory current and firing rate changes, similar to those observed in dynamic clamp experiments (Gauck and Jaeger, 2003). This observation is interesting in light of the temporal precision of Purkinje integration in the nuclei (Gauck and Jaeger, 2000; Person and Raman, 2011; Wu and Raman, 2017). Preferential drive of IN spiking by tonic excitatory currents suggests that excitatory afferents could influence the gain of Purkinje inputs but not their ability to temporally sculpt firing. Moreover, because IN neurons are autonomous pacemakers that fire spontaneously at $>50 \mathrm{~Hz}$ (Raman et al., 2000), tonic excitatory drive would enhance the intrinsic excitatory tone opposing Purkinje inhibition.

\section{Anatomical and physiological features of the IN-RNm pathway}

The comparatively weak RNm-IN synapses contrasted with strong IN-RNm synapses, which produced EPSCs over an order of magnitude larger. Previous studies have examined IN-RNm integration in vivo and concluded that this afferent is stable, showing little short-term plasticity (Toyama et al., 1968; Jiang et al., 2002). Our data, which are, to our knowledge, the first to definitively isolate these synapses physiologically, are in broad support of this claim, but do reveal modest depression (Jiang et al., 2002). Furthermore, these axons innervate an area of RNm that is nearly devoid of inhibitory neurons (Fig. 6). Indeed, this paucity of inhibitory neurons in RNm was noted in early studies, showing a progressive sparsening of GABAergic neurons in posterior RNm compared with more anterior regions where parvocellular RN becomes more prominent (Vuillon-Cacciuttolo et al., 1984). Our physiological data supported this anatomy: although electrical stimulation could elicit inhibition in RNm neurons, optogenetic stimulation of the IN-RNm pathway did not, despite producing EPSCs with amplitudes comparable to electrical stimulation. Although dendrites of inhibitory neurons may invade the RNm and be contacted by IN afferents, it appears that the organization of feedforward inhibition in $\mathrm{RNm}$ in relation to IN input is distinct from other areas. Future studies examining microcircuitry of RNm and perirubral areas will be important to 
dissect how diverse RNm afferents sculpt RNm activity and consequent motor behavior.

\section{References}

Anastasio TJ, Robinson DA (1989) The distributed representation of vestibulo-oculomotor signals by brain-stem neurons. Biol Cybern 61:7988. Medline

Anderson ME (1971) Cerebellar and cerebral inputs to physiologically identified efferent cell groups in the red nucleus of the cat. Brain Res 30:49-66. CrossRef Medline

Bengtsson F, Hesslow G (2006) Cerebellar control of the inferior olive. Cerebellum 5:7-14. CrossRef Medline

Brodal A, Gostad AC (1954) Rubro-cerebellar connections an experimental study in the cat. Anat Rec 118:455-485. CrossRef Medline

Brodal P, Bjaalie JG (1992) Organization of the pontine nuclei. Neurosci Res 13:83-118. CrossRef Medline

Brooks JX, Cullen KE (2009) Multimodal integration in rostral fastigial nucleus provides an estimate of body movement. J Neurosci 29:1049910511. CrossRef Medline

Cannon SC, Robinson DA, Shamma S (1983) A proposed neural network for the integrator of the oculomotor system. Biol Cybern 49:127-136. CrossRef Medline

Chan-Palay V (1977) Cerebellar dentate nucleus: organization, cytology and transmitters. New York: Springer.

Courville J (1968) Connections of the red nucleus with the cerebellum and certain caudal brain stem structures: a review with functional considerations. Rev Can Biol 27:127-144. Medline

Courville J, Brodal A (1966) Rubro-cerebellar connections in the cat: an experimental study with silver impregnation methods. J Comp Neurol 126:471-485. CrossRef Medline

Dietrichs E, Walberg F (1983) Cerebellar cortical afferents from the red nucleus in the cat. Exp Brain Res 50:353-358. Medline

Dietrichs E, Walberg F (1987) Cerebellar nuclear afferents: where do they originate? Anat Embryol 177:165-172. CrossRef Medline

Eccles JC, Scheid P, Táboríková H (1975) Responses of red nucleus neurons to antidromic and synaptic activation. J Neurophysiol 38:947-964. Medline

Fu YS, Tseng GF, Yin HS (1996) Extrinsic inhibitory innervation to rubral neurons in rat brain-stem slices. Exp Neurol 137:142-150. CrossRef Medline

Gauck V, Jaeger D (2000) The control of rate and timing of spikes in the deep cerebellar nuclei by inhibition. J Neurosci 20:3006-3016. Medline

Gauck V, Jaeger D (2003) The contribution of NMDA and AMPA conductances to the control of spiking in neurons of the deep cerebellar nuclei. J Neurosci 23:8109-8118. Medline

Gerrits NM, Voogd J (1987) The projection of the nucleus reticularis tegmenti pontis and adjacent regions of the pontine nuclei to the central cerebellar nuclei in the cat. J Comp Neurol 258:52-69. CrossRef Medline

Gibson AR, Houk JC, Kohlerman NJ (1985) Magnocellular red nucleus activity during different types of limb movement in the macaque monkey. J Physiol 358:527-549. CrossRef Medline

Herzfeld DJ, Shadmehr R (2016) Cerebellar output encodes a corrective saccadic command (Commentary on Sun et al.). Eur J Neurosci 44:25282530. CrossRef Medline

Herzfeld DJ, Kojima Y, Soetedjo R, Shadmehr R (2015) Encoding of action by the Purkinje cells of the cerebellum. Nature 526:439-442. CrossRef Medline

Hewitt AL, Popa LS, Pasalar S, Hendrix CM, Ebner TJ (2011) Representation of limb kinematics in Purkinje cell simple spike discharge is conserved across multiple tasks. J Neurophysiol 106:2232-2247. CrossRef Medline

Higo S, Akashi K, Sakimura K, Tamamaki N (2009) Subtypes of GABAergic neurons project axons in the neocortex. Front Neuroanat 3:25. CrossRef Medline

Hinman A, Carpenter MB (1959) Efferent fiber projections of the red nucleus in the cat. J Comp Neurol 113:61-82. CrossRef Medline

Horn KM, Hamm TM, Gibson AR (1998) Red nucleus stimulation inhibits within the inferior olive. J Neurophysiol 80:3127-3136. Medline

Houck BD, Person AL (2015) Cerebellar premotor output neurons collateralize to innervate the cerebellar cortex. J Comp Neurol 523:2254-2271. CrossRef Medline

Houk JC, Keifer J, Barto AG (1993) Distributed motor commands in the limb premotor network. Trends Neurosci 16:27-33. CrossRef Medline
Huang CC, Sugino K, Shima Y, Guo C, Bai S, Mensh BD, Nelson SB, Hantman AW (2013) Convergence of pontine and proprioceptive streams onto multimodal cerebellar granule cells. Elife 2:e00400. CrossRef Medline

Huisman AM, Kuypers HG, Verburgh CA (1981) Quantitative differences in collateralization of the descending spinal pathways from red nucleus and other brain stem cell groups in rat as demonstrated with the multiple fluorescent retrograde tracer technique. Brain Res 209:271-286. CrossRef Medline

Huisman AM, Kuypers HG, Condé F, Keizer K (1983) Collaterals of rubrospinal neurons to the cerebellum in rat: a retrograde fluorescent double labeling study. Brain Res 264:181-196. CrossRef Medline

Husson Z, Rousseau CV, Broll I, Zeilhofer HU, Dieudonné S (2014) Differential GABAergic and glycinergic inputs of inhibitory interneurons and purkinje cells to principal cells of the cerebellar nuclei. J Neurosci 34: 9418-9431. CrossRef Medline

Jiang MC, Alheid GF, Nunzi MG, Houk JC (2002) Cerebellar input to magnocellular neurons in the red nucleus of the mouse: synaptic analysis in horizontal brain slices incorporating cerebello-rubral pathways. Neuroscience 110:105-121. CrossRef Medline

Kawato M, Gomi H (1992) A computational model of four regions of the cerebellum based on feedback-error learning. Biol Cybern 68:95-103. CrossRef Medline

Kim EJ, Jacobs MW, Ito-Cole T, Callaway EM (2016) Improved monosynaptic neural circuit tracing using engineered rabies virus glycoproteins. Cell Rep 15:692-699. CrossRef Medline

Kohlerman NJ, Gibson AR, Houk JC (1982) Velocity signals related to hand movements recorded from red nucleus neurons in monkeys. Science 217: 857-860. CrossRef Medline

Lein ES, Hawrylycz MJ, Ao N, Ayres M, Bensinger A, Bernard A, Boe AF, Boguski MS, Brockway KS, Byrnes EJ, Chen L, Chen L, Chen TM, Chin MC, Chong J, Crook BE, Czaplinska A, Dang CN, Datta S, Dee NR, et al. (2007) Genome-wide atlas of gene expression in the adult mouse brain. Nature 445:168-176. Medline

Liang H, Paxinos G, Watson C (2012) The red nucleus and the rubrospinal projection in the mouse. Brain Struct Funct 217:221-232. CrossRef Medline

Luo Y, Sugihara I (2014) Cerebellar afferents originating from the medullary reticular formation that are different from mossy, climbing or monoaminergic fibers in the rat. Brain Res 1566:31-46. CrossRef Medline

Martin JH, Cooper SE, Hacking A, Ghez C (2000) Differential effects of deep cerebellar nuclei inactivation on reaching and adaptive control. J Neurophysiol 83:1886-1899. Medline

Murray HM, Gurule ME (1979) Origin of the rubrospinal tract of the rat. Neurosci Lett 14:19-23. CrossRef Medline

Najac M, Raman IM (2015) Integration of Purkinje cell inhibition by cerebellar nucleo-olivary neurons. J Neurosci 35:544-549. CrossRef Medline

Naus CG, Flumerfelt BA, Hrycyshyn AW (1984) Topographic specificity of aberrant cerebellorubral projections following neonatal hemicerebellectomy in the rat. Brain Res 309:1-15. CrossRef Medline

Pasalar S, Roitman AV, Durfee WK, Ebner TJ (2006) Force field effects on cerebellar Purkinje cell discharge with implications for internal models. Nat Neurosci 9:1404-1411. CrossRef Medline

Person AL, Raman IM (2011) Purkinje neuron synchrony elicits timelocked spiking in the cerebellar nuclei. Nature 481:502-505. CrossRef Medline

Popa LS, Hewitt AL, Ebner TJ (2012) Predictive and feedback performance errors are signaled in the simple spike discharge of individual Purkinje cells. J Neurosci 32:15345-15358. CrossRef Medline

Popa LS, Streng ML, Ebner TJ (2017) Long-term predictive and feedback encoding of motor signals in the simple spike discharge of Purkinje cells. eNeuro 4:ENEURO.0036-17.2017. CrossRef Medline

Quy PN, Fujita H, Sakamoto Y, Na J, Sugihara I (2011) Projection patterns of single mossy fiber axons originating from the dorsal column nuclei mapped on the aldolase $\mathrm{C}$ compartments in the rat cerebellar cortex. J Comp Neurol 519:874-899. CrossRef Medline

Rajan K, Harvey CD, Tank DW (2016) Recurrent network models of sequence generation and memory. Neuron 90:128-142. CrossRef Medline

Raman IM, Gustafson AE, Padgett D (2000) Ionic currents and spontaneous firing in neurons isolated from the cerebellar nuclei. J Neurosci 20: 9004-9016. Medline

Reid JM, Gwym DG, Flumerfelt BA (1975) A cytoarchitectonic and Golgi 
stody of the red nucleus in the rat. J Comp Neurol 162:337-361. CrossRef Medline

Robinson DA (1989) Integrating with neurons. Annu Rev Neurosci 12:3345. CrossRef Medline

Schmied A, Amalric M, Dormont JF, Farin D (1990) GABAergic mechanisms in the cat red nucleus: effects of intracerebral microinjections of muscimol or bicuculline on a conditioned motor task. Exp Brain Res 81:523532. CrossRef

Seung HS, Lee DD, Reis BY, Tank DW (2000) Stability of the memory of eye position in a recurrent network of conductance-based model neurons. Neuron 26:259-271. CrossRef Medline

Shinoda Y, Sugiuchi Y, Futami T, Izawa R (1992) Axon collaterals of mossy fibers from the pontine nucleus in the cerebellar dentate nucleus. J Neurophysiol 67:547-560. Medline

Toyama K, Tsukahara N, Udo M (1968) Nature of the cerebellar influences upon the red nucleus neurones. Exp Brain Res 4:292-309. CrossRef Medline

Toyama K, Tsukahara N, Kosaka K, Matsunami K (1970) Synaptic excitation of red nucleus neurones by fibres from interpositus nucleus. Exp Brain Res 11:187-198. Medline

Tsukahara N, Bando T, Murakami F, Oda Y (1983) Properties of cerebelloprecerebellar reverberating circuits. Brain Res 274:249-259. CrossRef Medline

Uusisaari M, Obata K, Knöpfel T (2007) Morphological and electrophysiological properties of GABAergic and non-GABAergic cells in the deep cerebellar nuclei. J Neurophysiol 97:901-911. CrossRef Medline

Vuillon-Cacciuttolo G, Bosler O, Nieoullon A (1984) GABA neurons in the cat red nucleus: a biochemical and immunohistochemical demonstration. Neurosci Lett 52:129-134. CrossRef Medline

Walberg F, Dietrichs E (1986) Is there a reciprocal connection between the red nucleus and the interposed cerebellar nuclei? Conclusions based on observations of anterograde and retrograde transport of peroxidaselabelled lectin in the same animal. Brain Res 397:73-85. CrossRef Medline

Wall NR, Wickersham IR, Cetin A, De La Parra M, Callaway EM (2010) Monosynaptic circuit tracing in vivo through Cre-dependent targeting and complementation of modified rabies virus. Proc Natl Acad Sci U S A 107:21848-21853. CrossRef Medline

Watabe-Uchida M, Zhu L, Ogawa SK, Vamanrao A, Uchida N (2012) Whole-brain mapping of direct inputs to midbrain dopamine neurons. Neuron 74:858-873. CrossRef Medline

Wickersham IR, Lyon DC, Barnard RJ, Mori T, Finke S, Conzelmann KK, Young JA, Callaway EM (2007) Monosynaptic restriction of transsynaptic tracing from single, genetically targeted neurons. Neuron 53:639647. CrossRef Medline

Wolpert DM (1997) Computational approaches to motor control. Trends Cogn Sci 1:209-216. CrossRef Medline

Wolpert DM, Miall RC, Kawato M (1998) Internal models in the cerebellum. Trends Cogn Sci 2:338-347. CrossRef Medline

Wu HS, Sugihara I, Shinoda Y (1999) Projection patterns of single mossy fibers originating from the lateral reticular nucleus in the rat cerebellar cortex and nuclei. J Comp Neurol 411:97-118. CrossRef Medline

Wu Y, Raman IM (2017) Facilitation of mossy fiber driven spiking in the cerebellar nuclei by the synchrony of inhibition. J Physiol 595:5245-5264. CrossRef Medline

Zeilhofer HU, Studler B, Arabadzisz D, Schweizer C, Ahmadi S, Layh B, Bösl MR, Fritschy JM (2005) Glycinergic neurons expressing enhanced green fluorescent protein in bacterial artificial chromosome transgenic mice. J Comp Neurol 482:123-141. CrossRef Medline

Zhao S, Ting JT, Atallah HE, Qiu L, Tan J, Gloss B, Augustine GJ, Deisseroth K, Luo M, Graybiel AM, Feng G (2011) Cell type-specific channelrhodopsin-2 transgenic mice for optogenetic dissection of neural circuitry function. Nat Methods 8:745-752. CrossRef Medline 